\title{
UPAYA MENINGKATKAN KEMAMPUAN KOGNITIF ANAK USIA 5-6 TAHUN MELALUI PERMAINAN PENCAMPURAN WARNA DENGAN PERCOBAAN SAINS SEDERHANA DI TK ISLAM SILMI SAMARINDA
}

\author{
Kartika Fajriani, Heppy Liana \\ Dosen Universitas Nahdlatul Ulama Kaltim \\ fajrianikatika111@yahoo.com,.heppy.liana@gmail.com
}

\begin{abstract}
ABSTRAK
Kemampuan kognitif diperlukan oleh anak dalam rangka mengembangkan pengetahuan tentang apa yang anak dengar, rasa, raba ataupun ia cium panca indera yang ia miliki.. Dalam pembelajaran kognitif khususnya pembelajaran sains masih banyak kendala yang terjadi di lapangan, salah satunya adalah kurangnya kreativitas guru dalam membuat media pembelajaran terutama dalam mengenalkan warna pada anak pada anak. Rumusan masalah dalam penelitian ini dapat di rumuskan sebagai berikut : Bagaimanakah meningkatkan kemampuan kognitif anak melalui kegiatan eksperimen pencampuran warna pada usia 5-6 tahun TK Islam Silmi? b) Apakah kegiatan mencampur warna dapat meningkatkan kemampuan kognitif anak usia 5-6 tahun TK Islam Silmi ? Tujuan penelitian ini adalah sebagai berikut : untuk meningkatkan kemampuan kognitif anak melalui pencampuran warna dengan kegiatan percobaan sains sederhana pada usia 5-6 tahun TK Islam Silmi. Berdasarkan hasil observasi dan penelitian dilakukan dengan berpedoman pada beberapa aspek atau indikator yang meliputi: Anak mampu melakukan percobaan mencampur warna, anak mampu mencampur dengan kesesuaian warna, anak mampu menceritakan hasil percobaa sains sederhana. Setelah dilaksanakan penelitian yang berjalan selama dua siklus, terbukti bahwa ternyata ada perubahan setelah dilakukan tindakan atau setelah diterapkan metode yang sesuai saat bermain mencampur warna. Berikut ini adalah penjelasan peningkatan hasil belajar pada siklus I dan siklus II, pada siklus I dengan rata-rata nilai persentase ketuntasan rata-rata mencapai 50\%, pada siklus II mengalami peningkatan dengan rata-rata nilai persentase ketuntasan mencapai 90\%. Kesimpulan yang dapat diambil dari penelitian ini adalah pencampuran warna dengan percobaa sains sederhana dapat meningkatkkan perkembangan kognitif di bidang sains pada anak usia 5-6 tahun TK Islam Silmi di Samarinda Utara.

Kata Kunci : Kemampuan kognitif, mengenal warna, mencampur warna, percobaan sains sederhana.
\end{abstract}

\section{PENDAHULUAN}

\section{A. Latar Belakang}

Pendidikan Anak Usia Dini (PAUD) merupakan upaya pemberian stimulasi bagi anak usia 0 - 6 tahun agar anak dapat tumbuh dan berkembang secara optimal baik jasmani dan rohani, sehingga tumbuh menjadi manusia yang beriman, bertaqwa, berbudi pekerti, cerdas, terampil, bertanggung jawab dan menjadi manusia pembangunan yang mampu mewujudkan kehidupan yang sejahtera dalam kehidupan bermasyarakat. Liana, Rahardjo, Sjamsir. 2018 mengatakan otak anak usia dini berkembang sangat 
cepat hingga 80 persen. Otak anak usia dini dalam hal ini aspek kognitif dapat menerima dan menyerap berbagai macam informasi, tidak melihat baik dan buruk. Itulah masa-masa yang dimana perkembangan fisik, kognitif, bahasa, seni, agama dan mental maupun spiritual anak akan mulai terbentuk. Karena itu, banyak yang menyebut masa tersebut sebagai masa-masa emas anak (golden age)

Pada dasarnya pengembangan kognitif dimaksudkan agar anak mampu melakukan eksplorasi terhadap dunia sekitar melalui panca indranya sehingga dengan pengetahuan yang di dapatnya maka anak akan dapat melangsungkan hidupnya dan menjadi manusia yang seutuhnya dan mampu memberdayakan apa yang ada di sekitarnya untuk kepentingan dirinya dan orang lain.

Perkembangan pemikiran atau kognitif anak tidak dapat berjalan sendiri tapi membutuhkan pengarahan dan pembelajaran dari orang yang lebih dewasa, baik orangtua maupun guru.

Untuk meningkatkan mutu pendidikan anak, sangat diperlukan pemahaman yang mendasar mengenai perkembangan diri anak terutama yang terjadi dalam proses pembelajaran. Hal ini dimaksudkan agar kita dapat mengetahui ada atau tidaknya kesulitan yang dialami oleh anak dalam proses belajarnya. Dengan pemahaman yang cukup mendalam atas proses tersebut diharapkan kita sebagai guru sebagai pemerhati pendidikan, mampu mengadakan eksplorasi, merencanakan dan mengimplementasikan penggunaan media dan sumber belajar anak usia dini dan juga mengaplikasikan pendekatan saintifik (scientific approach) untuk mengembangkan aspek kogintif anak usia dini sesuai dengan penerapan kurikulum PAUD 2013 seperti yang dikatakan oleh Liana, Utami. 2018 'The scientific approach is one of the approaches in building a way of thinking so that children have the ability to reason through the process of observing to communicate the results of his thought'.

Salah satu kegiatan yang dilaksanakan di lembaga PAUD dalam mengembangkan aspek kognitif AUD adalan Pencampuran warna. Dimana kegiatan ini adalah salah satu pembelajaran kognitif tentang sains. Melalui kegiatan ini anak dapat belajar dan bereksplorasi serta menemukan pengetahuan mereka tentang warna primer atau warna dasar dan warna sekunder yaitu hasil dari pencampuran warna dasar.

Dalam kegiatan-kegiatan tersebut yang dilakukan oleh anak usia 5-6 tahun TK Islam Silmi sering munculnya permasalahanpermasalahan. Adanya kemampuan berfikir anak sangat lambat, sulit membedakan warna di saat melakukan kegiatan eksperimen, anak-anak tidak memperhatikan disaat guru menerangkan.

Berdasarkan permasalahan yang ada peniliti merasa tertarik untuk meningkatkan kemampuan kognitif anak usia 5-6 tahun TK Islam Silmi dengan menggunakan media peraga pencampur warna secara sederhana.

Metode eksperimen menurut Djamarah (2002) adalah cara penyajian pelajaran, dimana siswa 
melakukan percobaan dengan mengalami sendiri sesuatu yang dipelajari. Dengan berekperimen siswa diberi kesempatan untuk mengalami sendiri atau melakukan sendiri, mengikuti suatu proses, mengamati suatu objek.

Dari latar belakang masalah yang ada, maka penulis mengidentifikas masalah tersebut sebagai berikut:

a. Anak-anak sering mengeluh apabila pembelajaran sulit dipecahkan

b. Sulit membedakan warna di saat melakukan kegiatan eksperimen

c. Anak-anak tidak memperhatikan disaat guru menerangkan.

1. Analisis Masalah

Dari masalah yang teridentifikasi, masalah yang akan dipecahkan adalah kurangnya kemampuan kognitif anak dalam mengenal dan membedakan warna dalam kegiatan eksperimen pencampuran warna. Penyebab masalah tersebut adalah karena materi serta media yang diajarkan guru kurang komunikatif dan kurang bervariatif. Sehingga anakpun merasa bosan dan tidak memperhatikan guru menerangkan di depan.

2. Alternatif dan Prioritas Pemecahan Masalah

Berdasarkan analisis masalah masalah yang ada di atas, maka peneliti memilih alternatif dan prioritas pemecahan masalah dengan menggunakan media dan metode yang tepat sehingga anak lebih semangat dan tertarik untuk belajar di kegiatan pengembangan kognitif sehingga kemampuan kognitif anak dapat meningkat lebih baik.

\section{KAJIAN PUSTAKA}

\section{Pengertian Kognitif}

Perkembangan kognitif anak usia dini adalah suatu proses berpikir berupa kema mpuan untuk menghubungkan, menilai dan mempertimbangkan sesuatu serta kemampuan untuk memecahkan masalah atau untuk mencipta karya.

Menurut Keat dalam Sitti Hartinah, secara umum perkembangan mental atau perkembangan kognitif sebagai proses-proses mental yang mencakup pemahaman tentang dunia, penemuan pengetahuan, pembuatan perbandingan, berpikir dan mengerti. Selanjutnya juga menjelaskan bahwa proses kognitif tersebut tidak lain adalah proses pengolahan informasi yang menjangkau kegiatan kognisi, intelegensia, belajar, pemecahan masalah dan pembentukan konsep. Secara lebih luas menjangkau kreativitas, imajinasi dan ingatan.

Albert Binet dalam Yuliani Nurani Sujiono dkk., 2006 mengatakan kognitif seseorang tercermin dalam kemampuannya menyelesaikan tugas-tugas yang menyangkut pemahaman dan penalaran. Terdapat tiga aspek kemampuan dalam intelegensi, yaitu:

1. Konsentrasi

Kemampuan memusatkan pikiran kepada suatu masalah yang harus dipecahkan.

2. Adaptasi

Kemampuan mengadakan adaptasi terhadap masalah yang dihadapinya.

3. Bersikap kritis

Kemampuan untuk mengadakan kritik, baik terhadap masalah yang dihadapi maupun terhadap dirinya sendiri.

\section{Pengertian Warna}

Warna adalah sebuah sensasi yang di hasilkan suatu energi 
cahaya mengenai suatu benda dimana cahaya tersebut akan di refleksikan secara langsung oleh benda yang terkena cahaya tadi.

Warna primer adalah warna merah, kuning, biru yang merupakan warna pokok atau warna dasar. Warna primer merupakan dasar dari terbentuknya semua warna dan kita bisa membentuk banyak jenis warna dari perpaduan warna-warna primer.

Warna Sekunder adalah warna kedua yang merupakan warna hasil perpaduan dari 2 warna primer. contohnya jika memadukan warna kuning dan warna biru maka akan menghasilkan warna hijau.warna sekunder terdiri dari warna hijau, ungu dan oranye.

\section{METODE PENELITIAN \\ Pendekatan Penelitian}

Penelitian ini merupakan jenis penelitian tindakan kelas. Penelitian tindakan kelas adalah suatu bentuk investigasi yang bersifat reflektif partisipatif, kolaboratif, dengan model siklus, yang memiliki tujuan untuk melakukan perbaikan sistem, metode kerja, proses, isi, kompetensi dan situasi.

\section{Latar Penelitian}

Penelitian dilaksanakan pada kelompok usia 5- 6 tahun TK Islam Silmi Samarinda. Penelitian dilaksanakan pada semester 2 tahun ajaran 2018. Subjek penelitiannya adalah murid TK Islam Silmi kelompok usia 5-6 tahun yang berjumlah 20 anak. TK Islam Silmi terletak di teritorial Samarinda Utara, di Jl. Wahid Hasyim.

\section{Prosedur Penelitian}

Penelitian dilaksanakan dengan model penelitian tindakan kelas (classroom action research). Dalam penelitian ini secara garis besar terdiri dari empat tahap kegiatan yaitu perencanaan, pelaksanaan tindakan, observasi, dan refleksi.

\section{Teknik Pengumpulan Data}

Untuk memperoleh data yang akurat dan dapat dipertanggung jawabkan, maka penulis mengumpulkan data dengan, metode dokumentasi dan observasi agar diperoleh data yang tepat, relevan dan akurat. Metode dokumentasi dimaksudkan untuk mendapatkan data tentang penilaian perkembangan anak, daftar nama dan jumlah siswa yang akan digunakan untuk menentukan populasi dan sampel dalam penelitian.

1. Metode Observasi

2. Metode Dokumentasi

\section{Teknik Analisis Data}

Analisis data dilakukan melalui dua tahap, yaitu membandingkan hasil pembelajaran dari siklus satu dan siklus dua, kemudian disimpulkan. Penyimpulan data adalah proses pengambilan intisari dan sajian data yang telah terorganisir dalam bentuk pernyataan kalimat yang singkat padat, tetapi mengandung pengertian yang luas. Analisis data dilakukan untuk melihat ketuntasan belajar anak dan peningkatan hasil belajar. Analisis ini dihitung menggunakan statistik sederhana, yaitu penilaian pencapaian prestasi.

\section{Indikator Keberhasilan}

Aspek-aspek yang digunakan sebagai indikator keberhasilan, yaitu:

1. Anak mampu melakukan percobaan mencampur warna

2. Anak mampu melakukan penyesuaian warna campuran

3. Anak mampu menceritakan hasil percobaan sederhana

\section{Instrumen Penelitian}

Berikut alat dan bahan yang digunakan untuk pencampuran warna dengan percobaan sederhana, yaitu: 
1. Pewarna makanan biru, merah dan kuning

2. Air

3. Gelas plastik

4. Botol plastik

5. Sedotan

6. Lem

7. Plywood sebagai alas

8. Kartu warna

9. Kartu angka

10. Kertas warna

\section{HASIL PENELITIAN \\ Deskripsi Siklus I}

a. Perencanaan

Sebelum melakukan penelitian tindakan kelas peneliti mempersiapkan:

1) Alat peraga,:

Alat peraga langsung yaitu media pencampur warna sederhan yang dibuat dari gelas plastik, sedotan dan botol plastik.

2) Menyusun teknik pelaksanaan kegiatan yang akan dilakukan.

3) Menyiapkan lembar-lembar observasi.

b. Pelaksanaan Tindakan

Adanya langkah-langkah pelaksanaan sebagai berikut:
1) Guru menyiapkan alat peraga pencampur warna.

2) Guru mengatur posisi anak. Posisi yang digunakan adalah posisi duduk berbaris menghadap alat peraga.

3) Guru mulai memperagakan kepada anak cara mencampur warna merah dan kuning, biru dan kuning lalu merah dan biru.

4) Guru memberi contoh bagaimana mencampur yang benar dengan komposisi yang pas.

5) Guru memberikan motivasi kepada anak yang belum mampu terampil mencampur warna

c. Observasi

Selama Siklus I berlangsung, melakukan pengamatan dibantu oleh guru pendamping. Pada kondisi awal sebelumnya, diketahui masih banyak anak yang dalam mencampur warna masih belum terampil maksudnya mereka hanya mengandalkan intuisinya saja dimana saat mencampur, hasil pencampuran warnanya ada yang belum sesuai.

Tabel 1. Penilaian pencapaian prestasi anak pada siklus I

\begin{tabular}{|l|l|l|l|l|l|l|}
\hline No & \multicolumn{1}{|c|}{ Penilaian } & A & B & C & D & Total anak \\
\hline 1 & Mencampur warna & 7 & 10 & 3 & & 20 \\
\hline 2 & Kesesuaian warna & 5 & 10 & 5 & & 20 \\
\hline 3 & $\begin{array}{l}\text { Menceritakan hasil } \\
\text { percobaan }\end{array}$ & 10 & 7 & 3 & & 20 \\
\hline & & & & & & \\
\hline
\end{tabular}

Keterangan:

$\mathrm{A}=$ Sangat Baik, $\mathrm{B}=$ Baik, $\mathrm{C}=$ Cukup, $\mathrm{D}=$ Kurang

Penilaian di atas dipersentasikan sebagai berikut:
1. Mencampur warna
2. Kesesuaian warna
$\underline{7} \times 100 \%=35 \%$
$\underline{5} \times 100 \%=25 \%$
20
3. Bercerita
$\underline{10} \times 100 \%=50 \%$
20 


$$
\begin{array}{lll}
\frac{10}{20} \times 100 \%=50 \% & \frac{10}{20} \times 100 \%=50 \% & \frac{7}{20} \times 100 \%=35 \% \\
\frac{3}{20} \times 100 \%=15 \% & \frac{5}{20} \times 100 \%=25 \% & \frac{3}{20} \times 100 \%=15 \%
\end{array}
$$

Dari data di atas dapat disimpulkan, pada kegiatan mencampur warna $35 \%$ sangat baik, $50 \%$ baik dan $15 \%$ cukup. Pada tahap kesesuaian warna campuran $25 \%$ sangat baik, $50 \%$ baik dan $25 \%$ cukup. Dan bercerita tentang percobaan $50 \%$ sangat baik, $35 \%$ baik dan $15 \%$ cukup.

Gambar 1. Grafik penilaian prestasi siklus I

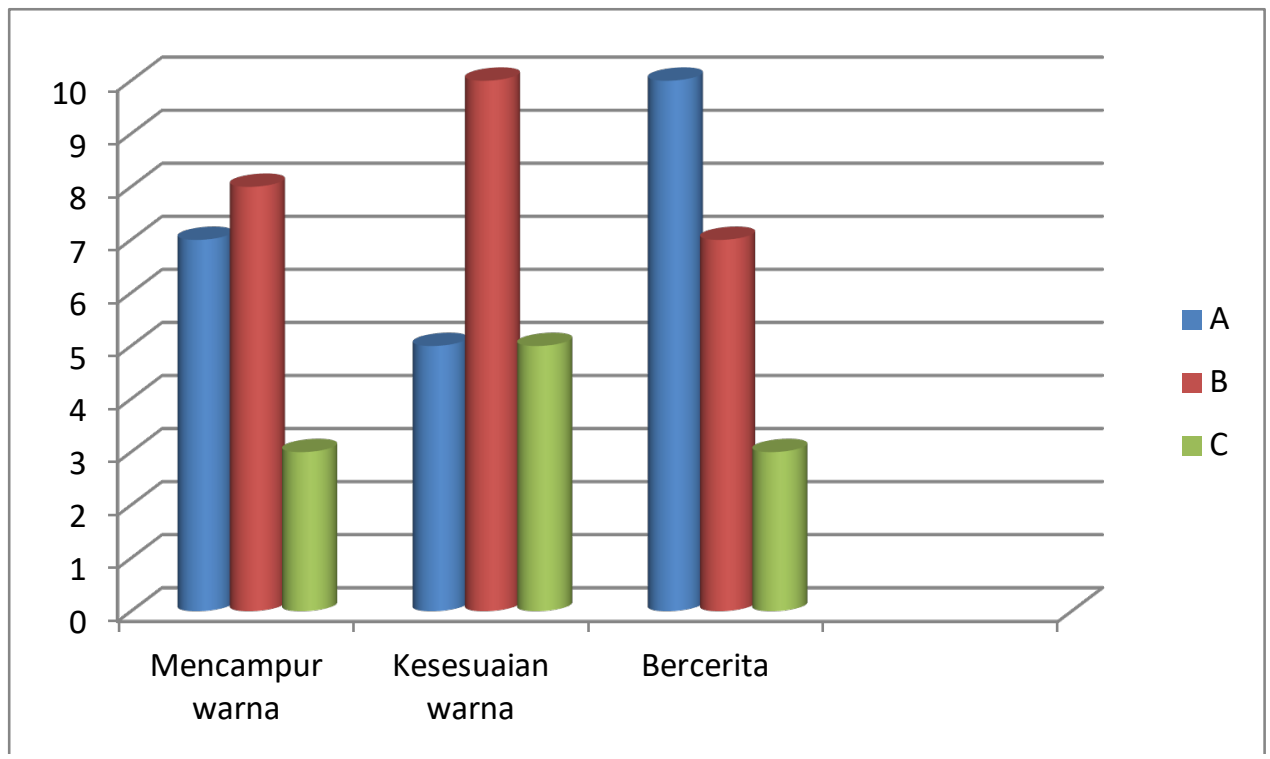

Dari grafik di atas dapat dijelaskan bahwa rendahnya persentase penilaian prestasi anak dari nilai ratarata pada seluruh aspek penilaian kemampuan kognitif pada siklus 1 sehingga sangat jauh dari nilai yang diharapkan. Maka akan dilanjutkan pada siklus II.

Beberapa kelemahan dalam proses pembelajaran ini adalah:

1. Sebagian besar anak belum fokus terhadap pembelajaran yang cenderung baru bagi mereka.
2. Masih banyak anak yang belum bisa dalam penyesuaian mencampur warna.

3. Ada banyak anak yang masih belum percaya diri dalam bercerita tentang hasil percobaan.

\section{Deskripsi Siklus II}

a. Perencanaan Tindakan

Perencanaan tindakan pada siklus II didasarkan hasil analisis pada siklus I. Diketahui kendala yang masih terjadi pada siklus I adalah 
anak-anak masih dibantu dalam kegiatan sains mencampur warna. Dengan demikian, pada siklus II guru diharapkan memperbaiki kualitas dan kuantitas pembelajaran dalam memotivasi anak.

\section{b. Kegiatan dan pelaksanaan}

Pada pelaksanaan tindakan siklus II tidak jauh beda dengan pelaksanaan tindakan siklus 1 . Pembelajaran dalam siklus menggunakan metode eksperimen bermain mencampur warna dengan percobaan sains sederhana tetapi dalam kegiatan ini lebih dikembangkan dan disempurnakan diharapkan supaya lebih baik dari siklus 1 .

Pelaksanaan kegiatan pembelajaran untuk siklus II di kelompok usia 5-6 tahun TK Islam Silmi dengan jumlah 20 anak yang mengikuti pembelajaran. Dalam penelitian ini peneliti bertindak sebagai guru.
Pembelajaran mengacu pada rencana pembelajaran yang termuat dalam rencana kegiatan harian.

Pelaksanaan proses pembelajaran yang dimulai dengan kegiatan awal, yaitu: mengucapkan salam, berdoa, mengabsen siswa dan mengkondisikan siswa dengan meminta siswa tenang dan duduk rapi. Anak-anak begitu berantusias dengan kegiatan tersebut karena anak terlibat langsung dalam permainan sains tersebut.

\section{c. Observasi}

Observasi dilaksanakan secara langsung bersamaan dengan pelaksanaan kegiatan pembelajaran. Pada tahapan ini dapat dilihat bagaimana guru sudah mulai melaksanakan bimbingan dengan mengajak anak-anak untuk memperhatikan penjelasan dari guru kemudian mengajak anak-anak bermain mencampur warna dengan media peraga yang disediakan.

Tabel 2. Penilaian pencapaian prestasi anak pada siklus II

\begin{tabular}{|l|l|c|c|c|c|c|}
\hline No & \multicolumn{1}{|c|}{ Penilaian } & A & B & C & D & Total anak \\
\hline 1 & Mencampur warna & 18 & 1 & 1 & & 20 \\
\hline 2 & Kesesuaian warna & 15 & 3 & 2 & & 20 \\
\hline 3 & $\begin{array}{l}\text { Menceritakan hasil } \\
\text { percobaan }\end{array}$ & 18 & 1 & 1 & & 20 \\
\hline
\end{tabular}

Penilaian di atas dipersentasikan sebagai berikut:
1. Mencampur warna
2. Kesesuaian warna
$\frac{18}{20} \times 100 \%=90 \%$ $\frac{18}{20}$
$15 \times 100 \%=75 \%$ 20
3. Bercerita
$\frac{18}{20} \times 100 \%=90 \%$
$\frac{18}{20}$
$\frac{1}{20} \times 100 \%=5 \%$
$\frac{3}{2} \times 100 \%=15 \%$
$\frac{5}{20} \times 100 \%=25 \%$
$\frac{1}{2} \times 100 \%=5 \%$
20
$\frac{2}{2} \times 100 \%=25 \%$
20
$\frac{1}{2} \times 100 \%=15 \%$

Dari data di atas dapat mencampur warna $95 \%$ sangat disimpulkan, pada kegiatan baik. Pada tahap kesesuaian warna 
campuran $75 \%$ sangat baik. Dan bercerita tentang hasil percobaan $70 \%$ sangat baik.

Gambar 2. Grafik penilaian prestasi siklus II

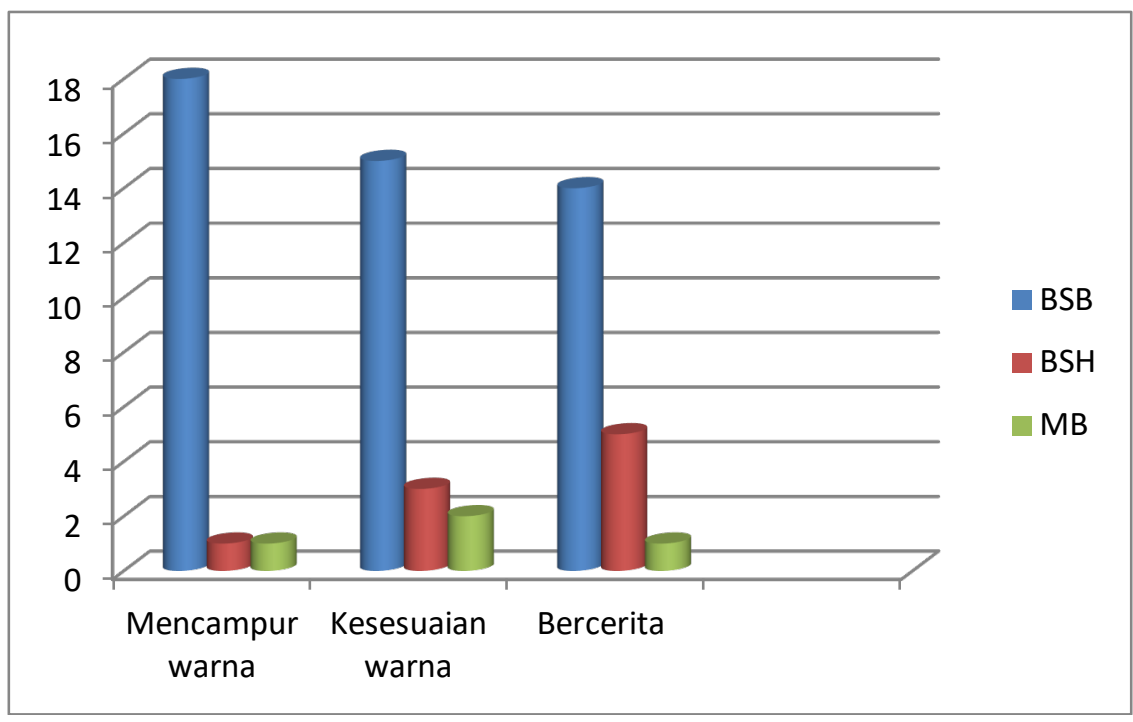

Dari grafik di atas disimpulkan juga bahwa anak yang mencapai ketuntasan atau indikator pada siklus II mencapai nilai rata-rata $90 \%$.

BSB Berkembang Sangat Baik : Anak mampu mencapai indikator dengan baik atau bahkan lebih (tuntas) BSH Berkembang Sesuai Harapan : Anak kurang mencapai indikator (kurang tuntas)

MB Mulai Berkembang : Anak mulai mencapai indikator

BB Belum Berkembang : Anak belum mencapai indikator (belum tuntas)

\section{d. Refleksi dan Analisis}

Berdasarkan pelaksanaan

kegiatan pada siklus II mendapatkan hasil dari 20 anak yang telah mengikuti kegiatan mencampur warna dengan percobaan sains sederhana sudah $90 \%$, mereka mampu mencampur warna dengan baik tanpa bantuan guru.

Beberapa kelebihan dalam proses pembelajaran ini, antara lain:

1. Siswa mampu mendengarkan apa yang disampaikan oleh guru tentang pengenalan warna dengan percobaan sains sederhana.

2. Proses belajar menjadi lebih menarik karena ada hal baru yang anak lakukan.

3. Asyiknya bereksperimen membuat campuran warna dimana anak langsung terlibat dalam melakukan percobaan tersebut.

\section{KESIMPULAN}

Dari hasil penelitian tindakan kelas yang peneliti lakukan dapat disimpulkan sebagai berikut :

1. Melalui kegiatan sains permainan mencampur warna dengan percobaan sederhana dapat 
meningkatkkan perkembangan kognitif di bidang sains pada anak usia 5-6 tahun TK Islam Silmi di Samarinda Utara.

2. Pada siklus I dengan rata-rata nilai persentase ketuntasan rata-rata mencapai 50\%, pada siklus II mengalami peningkatan dengan rata-rata nilai persentase ketuntasan mencapai $90 \%$.

\section{DAFTAR PUSTAKA}

Arikunto, Suharsimi, dkk. 2009. Penelitian Tindakan Kelas. Yogyakarta : Aditya Media.

Basuki. 2003. Teori dan Praktik Penelitian Tindakan. Bandung : Alfabeta.

Cahyo Agus N. 2011. Game Khusus Penyeimbang Otak Kanan dan Kiri Anak. Yogyakarta : Flash Books.

Depdiknas. 2002. Pedoman Pengembangan Silabus di Taman Kanak-Kanak. Jakarta : Depdiknas. 2004.

Hartini Sitti. 2010. Pengembangan Peserta Didik, Bandung: Refika Aditama.

Jamaris, Martini. 2006.

Perkembangan dan

Pengembangan Anak Usia

Taman Kanak-Kanak. Jakarta : Gramedia.

Kurikulum 2004 Standar Kompetensi Taman Kanak-kanak Dan Roudlotul Athfal. Jakarta : Departemen Pendidikan Nasional.
Kurniasih, Imas. 2009. Pendidikan Anak Usia Dini. Jakarta: Edukasia.

Lerin, Christine. 2009. 105

Permainan Untuk Meningkatkan Kecerdasan dan Kreativitas Buah Hati. Jakarta : Trans Media.

Liana, H. Rahardjo,B. Sjamsir, H. 2018. Implementasi Pembelajaran Karakter Anak Usia Dini di PAUD anak Kita Preschool Samarinda: http://jurnal.fkipuwgm.ac.id/index.php/pendasm ahakam/article/view/222/131

Liana, H. Utami, D. 2018. The Optimization of Early Childhood Scientific Approaches to Centre of Play in Kindergarten Fastabiqul Khairat Samarinda.

URL:

http://arpgweb.com/?ic=journal \&journal $=15 \&$ info $=$ aims

Martuti. 2009. Mengelola PAUD dengan Aneka Permainan Meraih Kecerdasan Majemuk. Yogyakarta : Kreasi Wacana.

Marzuki. 2002. Metodologi Riset. Yogyakarta : BPFE ULL.

Maulana, Rizky dan Amalia, Putri. 2009. Kamus Besar Bahasa Indonesia. Surabaya : Lima Bintang.

Moleong, Lexy J. 2009. Metodologi Penelitian Kualitatif. Bandung : Remaja Rosdakarya. 
Mulyati. 2005. Buku Pintar Belajar Matematika. Jogjakarta : Laksana.

Musfiroh. 2005. Bermain Sambil Belajar dan Mengasah Kecerdasan. Jakarta : Depdiknas.

Mushlich, Mansur. 2009. Melaksanakan Penelitian
Tindakan Kelas Itu Mudah Action Research Bagi Guru Profeional. Yogyakarta : Aditya Media.

Sujiono, Yuliani Nurani dkk., Metode Pengembangan Kognitif, Jakarta: Universitas Terbuka, 2006. 